\title{
AKIBAT HUKUM AKTA YANG DIBUAT NOTARIS PENGGANTI DI KOTA SEMARANG
}

\author{
Happy Yanua Riekayanti, Edith Ratna, Mujiono Hafidh Prasetyo \\ Program Studi Magister Kenotariatan \\ Fakultas Hukum, Universitas Diponegoro \\ Email: hriekayanti@gmail.com
}

\begin{abstract}
The position of a Notary Public Official is an honorary position given by the state attributively through the law, however if a notary is sentenced to a criminal sentence may be subject to sanctions in the Notary Position Act. The method used in this research is the empirical juridical method. The results of this study are the authority of a notary public in making a notarial deed in suspect status and legal protection of the parties. A notary public with a suspect status is still permitted to make a deed unless the notary is arrested because a notary must make a deed in his office. Legal certainty for the parties if a notary makes a deed in the status of a suspect, a deed made by a notary whose status as a suspect retains perfect proof of strength and fulfills the provisions of Article 16 paragraph (1) hurf 1, namely a Notary is obliged to read the deed before the attorney, attended by the attorney at least 2 (two) people are sanctioned and signed at the same time by the parties, witnesses, and notaries.
\end{abstract}

\section{Keywords : because of law; deed; substitute notary}

\begin{abstract}
Abstrak
Kedudukan Notaris Pengganti sebagai seorang pejabat umum merupakan suatu jabatan terhormat, namun apabila notaris Pengganti dapat dikenakan sanksi dalam Undang-Undang Jabatan Notaris. Metode pendekatan yang digunakan dalam penelitian ini adalah metode yuridis empiris. Hasil penelitian ini adalah kewenangan notaris pengganti dalam pembuatan akta notaris dalam membuat akta para pihak dan perlindungan hukum para pihak. Notaris pengganti harus membuat akta kecuali Notaris pengganti tersebut ditahan karena seorang Notaris pengganti harus membuat akta di kantornya. Kepastian hukum bagi para pihak apabila notaris pengganti membuat akta, Akta yang dibuat Notaris pengganti tetap memiliki kekuatan pembuktian yang sempurna serta memenuhi ketentuan Pasal 16 ayat (1) huruf 1 yaitu seorang Notaris pengganti berkewajiban membacakan akta dihadapan penghadap dengan dihadiri oleh paling sedikit 2 (dua) orang sanksi danditandatangani pada saat itu juga oleh penghadap, saksi, dan Notaris.
\end{abstract}

Kata kunci: akibat hukum; akta; notaris pengganti

\section{A. Pendahuluan}

Notaris merupakan pejabat umum yang berwenang untuk membuat akta otentik sejauh pembuatan akta otentik tertentu tidak dikhususkan bagi pejabat umum lainnya. Akte yang dibuat di hadapan notaris merupakan bukti otentik bukti sempurna, dengan segala akibatnya. (Kohar, 1983)

Jabatan dan profesi notaris pengganti sebagai produk hukum, sumbangsih dan peran sertanya semakin dibutuhkan untuk mengayomi masyarakat dan mendukung tegaknya 
supremasi hukum. Notaris tidak hanya bertugas membuat akta otentik semua perbuatan, perjanjian dan penetapan yang diharuskan oleh peraturan perundang-undangan atau yang berkepentingan untuk dinyatakan dalam akta otentik, tetepi juga harus dapat berfungsi membentuk hukum karena perjanjian antara pihak berlaku sebagai produk hukum yang mengikat para pihak. (Nico, 2003)

"Untuk dapat membuat akta otentik, seseorang harus mempunyai kedudukan sebagai pejabat umum. Di Indonesia, seorang Advokat, meskipun ia seorang yang ahli dalam bidang hukum, tidak berwenang untuk membuat akta otentik, karena ia tidak mempunyai kedudukan sebagai pejabat umum, sebaliknya seorang Pegawai Catatan Sipil meskipun ia bukan ahli hukum, ia berhak membuat akta-akta otentik untuk hal-hal tertentu, umpamanya untuk membuat akta kelahiran atau akta kematian. Demikian itu karena ia oleh Undang-undang ditetapkan sebagai pejabat umum dan diberi wewenang untuk membuat akta-akta itu". (Notodisoerjo, 1982)

Dalam Pasal 84 Undang-Undang Nomor 30 Tahun 2004 Tentang Jabatan Notaris menyatakan akta notaris yang mana akibat kelalaian Notaris pengganti dalam pembuatannya sehingga mengakibatkan akta tersebut hanya mempunyai kekuatan pembuktian sebagai akta di bawah tangan atau akta tersebut menjadi batal demi hukum, dapat menjadi alasan bagi pihak yang menderita kerugian untuk menuntut penggantian biaya, ganti rugi dan bunga kepada Notaris yang membuat akta tersebut.

Akhir-akhir ini banyak notaris pengganti yang dipanggil ke kantor polisi Kota Semarang, baik dalam kapasitasnya sebagai saksi atau diindikasikan menjadi tersangka, maupun yang sudah berstatus sebagai tahanan POLRI. Jumlah kasus tindak pidana yang melibatkan notaris, sejak tahun 2010 sampai 2015 di Direktorat Reskrim dan satuan Kota Semarang, sebanyak 53 kasus. Dimana 10 (sepuluh) orang Notaris Pengganti sebagai tersangka dan sisanya jadi saksi. Dalam pelaksanaan pemanggilan dan pemeriksaan notaris/PPAT telah ada suatu kesepakatan antara POLRI dengan Ikatan Notaris Indonesia yang tertuang dalam Nota Kesepahaman antara Kepolisian Negara Republik Indonesia dengan Ikatan Notaris Indonesia yaitu Nomor Pol:B/1056/V/2006 dan Nomor: 01/MOU/PPINI/V/2006 Tanggal 9 Mei 2006, Nota Kesepahaman Antara Kepolisian Negara Republik Indonesia Dengan Ikatan Pejabat Pembuat Akta Tanah Nomor Pol: B/1055/V/2006 Dan Nomor: 05/PP-IPPAT/V/2006 Tanggal 9 Mei 2006 Tentang Pembinaan Dan Peningkatan Profesionalisme Di Bidang Penegakan Hukum.

Notaris pengganti yang melanggar hukum dalam melaksanakan jabatannya baik disengaja maupun karena kelalaian kini tidak bisa tenang lagi. Pihak-pihak yang merasa dirugikan dapat membuat pengaduan ke pihak Majelis Pengawas Notaris dan Kepolisian. 
Apabila Notaris pengganti mengabaikan tugas jabatannya dan keluhuran dari martabatnya dan melakukan pelanggaran terhadap Undang-Undang Nomor 30 Tahun 2004 tentang Jabatan Notaris dan peraturan perundang-undangan lainnya yang berlaku maka Majelis Pengawas dapat bertindak tegas mengenakan sanksi. Bahkan dapat memberikan rekomendasi kepada Menteri Hukum dan Hak Asasi Manusia untuk mencabut izin operasionalnya. Kepada Notaris yang bersangkutan tidak tertutup kemungkinan untuk dituntut ke pengadilan, baik dalam perkara pidana maupun perkara perdata. (Budiono, 2007)

Adapun pasal-pasal tindak pidana yang sering muncul dalam pelaksanaan tugas notaris dalam Kitab Undang-Undang Hukum Pidana yaitu dalam Pasal 263 KUHP jo Pasal 264 Ayat (1) KUHP tentang Pemalsuan Surat. Dalam Pasal 263 KUHP tersebut ada 2 (dua) macam pemalsuan surat, yaitu :

1. Membuat surat palsu (valscheelijkop maakt) yaitu perbuatan membuat surat yang isinya bukan semestinya atau isinya tidak benar. Dalam hal ini dibuat suatu surat yang isinya tidak benar namun suratnya sendiri asli atau sering disebut aspal (asli tapi palsu) karena tidak ada sesuatu yang dirubah, ditambah ataupun dikurangi.

2. Memalsukan surat (vervalscht) yaitu memalsukan surat-surat dengan cara merubah, menambah, mengurangi atau menghapus sebagian tulisan yang ada dalam suatu surat. Jadi suratnya sudah ada tetapi surat itu kemudian dilakukan perubahan sehingga bunyi dan maksudnya berbeda dari aslinya.

Sedangkan Pasal 264 KUHP hanyalah merupakan pemberatan dari tindak pidana yang diatur dalam Pasal 263 KUHP.

MPW/MPD kepada notaris bisa merupakan penetapan bahwa notaris tersebut hanya Perlindungan hukum yang diberikan oleh ditetapkan sebagai saksi atas akta yang dibuatnya apabila akta tersebut di kemudian hari digugat oleh pihak lain yang menuduh notaris pengganti telah melakukan penipuan. (Effendi, 1993) Hal seperti ini dapat dihindari notaris dengan cara mengkopi segala surat-surat yang berhubungan dengan pembuatan akta dan menjahitkannya pada akta tersebut karena notaris hanya membuat akta berdasarkan keterangan dari para penghadap dan surat-surat lain yang mendukung dalam pembuatan akta tersebut. Dengan demikian notaris pengganti dapat menghindarkan diri sebagai tersangka ataupun turut membantu terciptanya akta yang palsu atau tidak benar.

Pandangan Aristoteles tentang keadilan bisa didapatkan dalam karyanya nichomachean ethics, politics, dan rethoric. Spesifik dilihat dalam buku nicomachean ethics, buku itu sepenuhnya ditujukan bagi keadilan, yang, berdasarkan filsafat hukum Aristoteles, mesti 
dianggap sebagai inti dari filsafat hukumnya, "karena hukum hanya bisa ditetapkan dalam kaitannya dengan keadilan”. (Apeldoorn, 1996)

Pada pokoknya pandangan keadilan ini sebagai suatu pemberian hak persamaan tapi bukan persamarataan. Aristoteles membedakan hak persamaanya sesuai dengan hak proposional. Kesamaan hak di pandangan manusia sebagai suatu unit atau wadah yang sama. Inilah yang dapat dipahami bahwa semua orang atau setiap warga negara dihadapan hukum sama. Kesamaan proposional memberi tiap orang apa yang menjadi haknya sesuai dengan kemampuan dan prestasi yang telah dilakukanya.

Teori keadilan yang memiliki arti persamaan terhadap pemenuhan hak kesehatan seperti teori keadilan Aristoteles yaitu teori keadilan oleh John Rawls. John Rawls dipandang sebagai perspektif "liberal-egalitarian of social justice", berpendapat bahwa keadilan adalah kebajikan utama dari hadirnya institusi-institusi sosial (social institutions). Kebajikan bagi seluruh masyarakat tidak dapat mengesampingkan atau menggugat rasa keadilan dari setiap orang yang telah memperoleh rasa keadilan, khususnya masyarakat lemah pencari keadilan. (Faiz, 2009)

Berdasarkan uraian dalam latar belakang dirumuskan tiga permasalahan sebagai berikut: 1) Bagimana Akibat Hukum Akta Yang Dibuat Notaris Pengganti di Kota Semarang, 2) Bagaimana Legalitas Akta Yang Dibuat Notaris Pengganti di Kota Semarang.

Fakta menunjukkan bahwa belum banyak hasil penelitian yang berkaitan dengan obyek penelitian baik dalam bentuk laporan, skripsi, tesis maupun disertasi. Namun khusus untuk penelitian hukum, dengan keterbatasan kemampuan penulis untuk menelusuri hasil-hasil penelitian di bidang hukum, ada beberapa penelitian tentang penerapan doktrin persamaan pada "Akibat Hukum Akta Yang Dibuat Notaris Pengganti Di Kota Semarang"

Berdasarkan hasil penelusuran, penulis mendapat penelitian dalam bentuk jurnal yang ditulis oleh Ghansham Ananddi tahun 2016 dengan judul "Pengawasan terhadap Notaris dalam Kaitannya dengan Kepatuhan Menjalankan Jabatan”, yang mengungkapkan dua pokok permasalahan, yaitu: pertama bagaimana pengawasan yang dilakukan oleh Majelis Pengawas untuk mencegah terjadinya penyalahgunaan Jabatan Notaris. Kedua bagaimana majelis pengawas notaris sebagai instansi yang melakukan pengawasan terhadapNotaris. (Anand dan Syafruddin, 2016)

Jurnal yang ditulis oleh Mokhamad Dafirul Fajar Rahman padatahun 2014 dengan judul "Kewenangan, Kewajiban Notaris dan Calon Notaris dalam Membuat Akta Autentik" yang 
mengungkapkanpermasalahan yaitu: bagaimana analisis yuridis Pasal 16 ayat (1) huruf a dengan Pasal 16 A Undang-Undang Republik Indonesia Nomor 2 Tahun 2014 Tentang Perubahan Atas Undang-Undang Nomor 30 Tahun 2004 Tentang Jabatan Notaris wewenang Notaris dan Calon Notaris dalam membuat akta terkait Kewenangan Notaris dan Calon Notaris Dalam Membuat Akta Otentik. (Rahman, 2014)

Jurnal yang ditulis oleh Wibby Yuda Prakoso pada tahun 2017 dengan judul “ Tanggung Jawab Dan Akibat Hukum Dari Akta Notariil Yang Dibuat Oleh Notaris Pengganti Setelah Masa Jabatannya Selesai" yang mengungkapkan permasalahan yaitu: Tanggung Jawab Notaris Penggati atas Akta yang dibuatnya. Dan Akibat Hukum dari Akta Notariil yang dibuat oleh Notaris Pengganti. (Prakoso, 2017)

Jurnal yang ditulis oleh Irma Mulia Fitri pada tahun 2019 dengan judul "Pengawasan dan Pembinaan Majelis Pengawas Daerah terhadap Notaris yang Melakukan Pelanggaran" yang mengungkapkan permasalahan yaitu: bagaimana bentuk pengawasan dan pembinaan Majelis Pengawas Daerah terhadap Notaris yang Melakukan Pelanggaran dan untuk menjelaskan Kendala yang dihadapi Majelis Pengawas Daerah dalam melakukan Pengawas dan Pembinaan. (Fitri, 2019)

\section{B. Metode Penelitian}

Metode pendekatan yang digunakan dalam penelitian ini adalah metode yuridis empiris. Yuridis mengandung makna bahwa penelitian ini dianalisis menggunakan berbagai buku-buku, peraturan perundang-undangan di bidang kenotariatan sebagai data sekunder. (Soemitro, 1990) Metode yuridis empiris dalam penelitian ini meninjau dan melihat serta menganalisa permasalahan yang menjadi objek penelitian yaitu Akibat Hukum Akta Yang Dibuat Notaris Pengganti di Kota Semarang.

\section{Hasil Dan Pembahasan}

\section{Akibat Hukum Akta Yang Dibuat Notaris Pengganti di Kota Semarang}

Pengaturan sanksi administratif disinkronisasi antara pengaturan sanksi administratif yang tercantum dalam Undang-Undang Jabatan Notaris (UUJN) dengan Peraturan Menteri Hukum Dan Hak Asasi Manusia Republik Indonesia Nomor M.02.PR.08.10 Tahun 2004, tersebut dari segi kewenangan. Menurut Pasal 73 ayat (1) huruf e dan ayat (2) UUJN, 
kewenangan MPW hanya dapat menjatuhkan sanksi teguran lisan dan teguran tertulis. Sanksi seperti ini final, artinya tidak ada upaya hukum lain, dan MPP hanya dapat menjatuhkan sanksi berupa pemberhentian sementara dari jabatannya (Pasal 77 Huruf c UUJN). Dengan demikian, kewenangan menjatuhkan sanksi seperti tersebut di atas hanya ada pada MPW dan MPP, tapi ternyata dalam Pasal 31 Ayat (1) dan (2) Peraturan Menteri itu disebutkan pula bahwa Majelis Pemeriksa (Wilayah dan Pusat) dari hasil pemeriksaannya dapat menjatuhkan sanksi berupa: teguranlisan dan teguran tertulis, pemberhentian sementara, pemberhentian dengan hormat dan pemberhentian dengan tidak hormat.

Majelis Pemeriksa dapat menjatuhkan sanksi yang lebih luas dibandingkan dengan sanksi yang dapat dijatuhkan oleh MPW dan MPP kepada Notaris, yaitu MPW dan MPP atau Majelis Pemeriksa Wilayah dan Majelis Pemeriksa Pusat. Substansi peraturan menteri di atas tidak tepat untuk dilaksanakan karena mencampuradukan kewenangan MPW dan Majelis Pemeriksa Wilayah serta Majelis Pemeriksa Pusat dalam menjatuhkan sanksi, sehingga yang tetap harus dijadikan pedoman adalah aturan hukum yang lebih tinggi yaitu UUJN.

Sanksi yang dijatuhkan oleh Majelis Pengawas tersebut, Notaris pengganti di Kota Semarang diberi kesempatan untuk mengajukan keberatan kepada Majelis Pengawas yang menjatuhkan sanksi kepadanya. Jika tidak puas dapat mengajukan banding kepada instansi Majelis Pengawas yang lebih tinggi. Gugatan ke pengadilan tata usaha negara pun dapat dilakukan jika putusan Majelis Pengawas tetap tidak memuaskan Notaris pengganti di Kota Semarang yang bersangkutan.

Dalam Pasal 6 Peraturan Menteri Hukum dan HAM Nomor: M.03.HT.03.10 Tahun 2007 tentang Pengambilan Minuta Akta dan Pemanggilan Notaris Pengganti, ditegaskan bahwa Majelis Pengawas Daerah (MPD) wajib memberikan persetujuan atau tidak memberikan persetujuan secara tertulis dalam jangka waktu paling lama 14 (empat belas) hari terhitung sejak diterimanya surat permohonan, dan apabila dalam jangka waktu 14 (empat belas) hari terlampaui tidak ada surat keputusan MPD tentang persetujuan atau menolak permintaan penyidik, penuntut umum, atau hakim, maka Majelis Pengawas Daerah dianggap menyetujui untuk dilakukan pemeriksaan terhadap Notaris pengganti di Kota Semarang yang bersangkutan oleh penyidik, penuntut umum, atau hakim tersebut.

Hasil akhir dari pemeriksaan yang dilakukan oleh MPD berupa Surat Keputusan (yang merupakan suatu penetapan tertulis). Surat Keputusan tersebut bersifat konkrit, individual, 
final dan menimbulkan akibat hukum. Konkrit artinya objek yang diputuskan bukan suatu hal yang abstrak, tapi dalam hal ini objeknya yaitu akta tertentu yang diperiksa oleh MPD yang dibuat oleh Notaris pengganti di Kota Semarang bersangkutan. Individual artinya keputusan tidak ditujukan kepada umum atau kepada semua orang, tapi kepada nama Notaris yang bersangkutan. Final artinya sudah definitif, yang tidak memerlukan persetujuan dari pihak lain atau institusi atasannya, sehingga hal ini dapat menimbulkan akibat hukum tertentu bagi Notaris pengganti di Kota Semarang yang bersangkutan. Ketentuan semacam ini hanya berlaku untuk Surat Keputusan MPD sebagai penerapan dari Pasal 66 UUJN.

MPD yang memutuskan meloloskan Notaris untuk diperiksa oleh pihak lain sebagai pelaksanaan Pasal 66 UUJN, jika tidak memuaskan bagi Notaris Dengan demikian tindakan atau berkeberatan dengan alasan yang diketahui oleh Notaris Dengan demikian tindakan sendiri, (Thamrin, 2010) maka Notaris yang bersangkutan dapat menggugat MPD ke Pengadilan Tata Usaha Negara. Surat Keputusan MPD tersebut merupakan objek gugatan di Pengadilan Tata Usaha Negara.

Perlindungan hukum yang disebutkan di atas mempunyai batasan-batasan tertentu, yaitu hanya berlaku ketika Notaris menjalankan tugas jabatannya sesuai dengan wewenang Notaris pengganti di Kota Semarang dan tidak berlaku jika tindakan Notaris tidak dalam menjalankan tugas jabatannya atau tidak sesuai dengan wewenang Notaris. (Tedjosaputro, 1995) Contohnya seorang Notaris pengganti di Kota Semarang dalam kapasitasnya sebagai pribadi atau sebagai pengusaha (terlepas dari tugas jabatannya sebagai Notaris) yang dalam menjalankan usahanya tersebut mempergunakan atribut Notarisnya. Tindakan Notaris pengganti di Kota Semarang tersebut itu dapat dikategorikan sebagai melakukan perbuatan yang merendahkan kehormatan dan martabat jabatan Notaris pengganti di Kota Semarang (Pasal 12 huruf c UUJN), maka hal tersebut dapat dijadikan dasar oleh Majelis Pengawas Pusat Notaris pengganti di Kota Semarang untuk mengusulkan kepada Menteri agar Notaris pengganti di Kota Semarang yang bersangkutan diberhentikan dengan tidak hormat sebagai Notaris. (Adjie, 2008)

Dengan demikian, UUJN memberikan perlindungan hukum bagi Notris sepanjang menjalankan tugas jabatannya sesuai dengan wewenang Notaris pengganti di Kota Semarang dan tidak berlaku jika Notaris pengganti di Kota Semarang melakukan suatu tindakan tidak dalam menajalankan tugas jabatannya selaku Notaris pengganti di Kota Semarang atau di luar wewenang Notaris. 
Sebagai seseorang yang belum dinyatakan bersalah maka ia mendapat hak-hak seperti: hak untuk segera mendapatkan pemeriksaan dalam phase penyidikan, hak segera mendapat pemeriksaan oleh pengadilan dan mendapat putusan seadil-adilnya, hak untuk diberitahu hal tentang apa yang disangkakan/didakwakan kepadanya dengan bahasa yang dimengerti olehnya, hak untuk menyiapkan pembelaannya, hak untuk mendapat juru bahasa, hak untuk mendapatkan bantuan hukum dan hak untuk mendapatkan kunjungan keluarganya. (Salam, 2001)

Peraturan Jabatan Notaris pengganti di Kota Semarang Pada Pasal 51 menyatakan bahwa Notaris pengganti di Kota Semarang yang terhadapnya dilakukan surat perintah penahanan sementara, dengan sendirinya menurut hukum telah dipecat dari jabatannya, sampai ia dibebaskan kembali.

Akibat hukum dari penetapan status tersangka kepada seorang Notaris pengganti di Kota Semarang di luar kewenangan pembuatan akta yaitu mengenai cuti Notaris. Seorang Notaris memiliki hak untuk cuti. Cuti Notaris pengganti di Kota Semarang diatur dalam UUJN, dengan catatan bahwaselama jabatannya cuti seorang Notaris pengganti di Kota Semarang tidak boleh melebihi 12 tahun. Cuti diijinkan bagi Notaris pengganti di Kota Semarang yang sudah menjabat 2 (dua) tahun. Untuk Notaris pengganti di Kota Semarang yang berstatus sebagai tersangka yang akan mengajukan cuti kemungkinan permohonan cuti tersebut akan ditolak untuk menghindari tersangka tersebut menghindar atau kabur ke luar negeri.

Tidak terdapat akibat hukum secara spesifik dalam peraturan mengenai penetapan status tersangka terhadap seorang Notaris pengganti di Kota Semarang dalam melaksanakan tugas sebagai jabatan umum. Seorang Notaris pengganti di Kota Semarang dalam statusnya sebagai tersangka tetap berkewajiban melaksanakan tugasnya sebagai pejabat umum yaitu membuat akta otentik.

Jadi dapat dikatakan bahwa notaris pengganti di Kota Semarang yang berstatus sebagai tersangka belum membawa akibat hukum terhadap tugas jabatan profesinya. Akibat hukum terhadap notaris pengganti di Kota Semarang dalam menjalankan tugas jabatan profesinya baru akan timbul pada saat notaris pengganti di Kota Semarang tersebut telah dinyatakan bersalah melakukan suatu tindak pidana yang diancam pidana penjara 5 (lima) tahun atau lebih berdasarkanputusan pengadilan yang berkekuatan hukum tetap. 
Notaris pengganti di Kota Semarang diberhentikan dengan tidak hormat oleh Menteri karena dijatuhi pidana penjara berdasarkan putusan pengadilan yang telah memperoleh kekuatan hukum tetap karena melakukan tindak pidana yang diancam dengan pidana penjara 5 (lima) tahun atau lebih.

\section{Legalitas Akta yang Dibuat Notaris Pengganti di Kota Semarang}

\section{a. Syarat Otentisitas Suatu Akta}

Akta sebagai alat bukti yang sengaja dibuat yang nantinya apabila diperlukan dapat dipergunakan sebagai alat pembuktian mempunyai peranan yang penting dalam kehidupan masyarakat yang modern, (Santoso, 2013) oleh karena akta sebagai dokumen tertulis dapat memberikan bukti akan adanya suatu peristiwa hukum yang di dalamnya mengatur hak dan kewajiban masing-masing pihak yang melakukan perikatan. Pembuktian itu sendiri diperlukan apabila timbul suatu perselisihan.

Ada 2 (dua) jenis/golongan akta Notaris, yaitu:

1) akta yang dibuat oleh (door) Notaris, biasa disebut dengan istilah Akta Relaas atau Berita Acara,

2) aktayang dibuat di hadapan (ten overstaan) Notaris, biasa disebut dengan istilah Akta Pihak atau Akta Partij.

Akta-akta tersebut dibuat atas dasar permintaan para pihak/penghadap, tanpa adanya permintaan para pihak, sudah tentu akta tersebut tidak akan dibuat oleh Notaris. Akta Relaas merupakan akta yang dibuat oleh Notaris pengganti di Kota Semarang atas permintaan para pihak, agar Notaris pengganti di Kota Semarang mencatat atau menuliskan segala sesuatu hal yang dibicarakan oleh pihak berkaitan dengan tindakan hukum atau tindakan lainnya yang dilakukan oleh para pihak, agar tindakan tersebut dibuat atau dituangkan dalam suatu akta Notaris. (Tobing, 1999) Dalam Akta Relaas ini Notaris pengganti di Kota Semarang menulis atau mencatatkan semua hal yang dilihat atau didengar sendiri secara langsung oleh Notaris pengganti di Kota Semarang yang dilakukan para pihak. Dan Akta Pihak adalah akta yang dibuat di hadapan Notaris pengganti di Kota Semarang atas permintaan para pihak, Notaris pengganti di Kota Semarang berkewajiban untuk mendengarkan pernyataan atau keterangan para pihak yang dinyatakan atau diterangkan sendiri oleh para pihak di hadapan Notaris.

Syarat-syarat otentisitas atau syarat-syarat Verlijden akta adalah disusun, dibacakan dan ditandatangani. Syarat ini harus dilakukan, jika tidak akta tersebut tidak mempunyai kekuatan akta otentik (berubah fungsinya menjadi akta di bawah tangan). Jika penghadap 
tidak mampu/ tidak bisa/berhalangan membubuhkan tanda tangan, maka ada pengganti tanda tangan (surrogate), yaitu suatu keterangan dari para penghadap karena tidak dapat menandatangani aktanya.

Pembacaan akta dan penandatanganan akta harus dilaksanakan pada saat yang bersamaan, dengan dihadiri oleh paling sedikit dua orang saksi artinya ketika dibacakan lalu dilanjutkan dengan penandatanganan akta oleh para penghadap Notaris pengganti di Kota Semarang harus hadir secara fisik dan menandatangani akta di hadapan penghadap dan saksi.

Mengingat besarnya tanggung jawab yang disandang oleh seorang Notaris, maka jabatan Notaris pengganti di Kota Semarang dijalankan oleh mereka yang selain memiliki kemampuan ilmu hukum yang memadai harus pula dijabat oleh mereka yang beretika dan berakhlak tinggi, perilaku Notaris pengganti di Kota Semarang karena tidak disiplin atau melanggar pelaksanaan jabatan Notaris pengganti di Kota Semarang dapat membawa akibat fatal terhadap akta yang dibuatnya. (Budiono, 2008)

Suatu akta dikatakan otentik apabila memenuhi syarat sebagai berikut :

a) Akta yang dibuat oleh atau akta yang dibuat di hadapan pegawai umum yang ditunjuk oleh undang-undang;

b) Bentuk akta yang ditentukan oleh undang-undang dan cara membuat akta menurut ketentuan yang ditetapkan undang-undang;

c) Ditempat dimana pejabat yang berwenang membuat akta tersebut.

Akta otentik mempunyai arti yang lebih penting daripada sebagai alat bukti, bila terjadi sengketa maka akta otentik dapat digunakan sebagai pedoman bagi para pihak yang bersangkutan.

Cacatnya akta Notaris pengganti di Kota Semarang dapat menimbulkan kebatalan bagi suatu akta Notaris Pengganti di Kota Semarang dan ditinjau dari sanksi atau akibat hukum dari kebatalan dapat dibedakan menjadi:

a) Batal demi hukum

b) Dapat dibatalkan

c) Non existent

Dapat dibatalkan adalah sanksi terhadap suatu perbuatan hukum yang mengandung cacat yuridis (penyebab kebatalan) berupa pembatalan perbuatan hukum dari pembatalan itu yaitu perbuatan hukum tersebut tidak mempunyai akibat hukum sejak terjadinya pembatalan, dan pembatalan atau pengesahan perbuuatan hukum tersebut tergantung pada pihak tertentu, yang menyebabkan perbuatan hukum tersebut dapat dibatalkan atau 
disahkan. (Chomzah, 2002) Akta yang sanksinya dapat dibatalkan, tetap berlaku dan mengikat selama belum ada putusan pengadilan yang telah mempunyai kekuatan hukum tetap yang membatalkan akta tersebut.

Sanksi Non Existent dikenakan terhadap perbuatan hukum yang tidak memenuhi bentuk pada perjanjian formil dan atau tidak dipenuhinya essentialia atau satu atau beberapa unsur yang mutlak yang ada untuk terbentuknya suatu perjanjian.

\section{b. Asas Praduga Sah dalam Menilai Akta Notaris}

Akta Notaris pengganti di Kota Semarang sebagai produk pejabat publik, maka penilaian terhadap akta Notaris pengganti di Kota Semarang harus dilakukan dengan asas praduga sah (vermoedenvanrechtmatigeheid) atau presumption iustae causa.(Hadjon, 1993) Asas ini dapat dipergunakan untuk menilai akta Notaris, yaitu dimana akta Notaris pengganti di Kota Semarang tersebut dianggap sah sampai ada pihak yang menyatakan akta tersebut tidak sah. Untuk menyatakan atau menilai akta tersebut tidak sah harus dengan gugatan ke pengadilan umum. Selama dan sepanjang gugatan berjalan sampai dengan ada keputusan pengadilan yang mempunyai kekuatan hukum tetap (inkracht), makaakta Notaris Pengganti di Kota Semarang tetap mengikat para pihak atau siapa saja yang berkepentingan dengan akta tersebut.

Dengan menerapkan asas praduga sah untuk akta Notaris, maka ketentuan yang tersebut dalam Pasal 84 UUJN yang menegaskan jika Notaris pengganti di Kota Semarang melanggar (tidak melakukan) ketentuan sebagaimana dimaksud dalam Pasal 16 ayat (1) huruf i, k, Pasal 41, Pasal 44, Pasal 48, Pasal 49, Pasal 50, Pasal 51, Pasal 52. Akta yang bersangkutan hanya mempunyai kekuatan pembuktian sebagai akta di bawah tangan tidak diperlukan lagi, maka kebatalan akta Notaris pengganti di Kota Semarang hanya berupa dapat dibatalkan atau batal demi hukum.

Asas praduga sah ini berkaitan dengan akta yang dapat dibatalkan, merupakan suatu tindakan mengandung cacat, yaitu tidak berwenangnya Notaris pengganti di Kota Semarang untuk membuat akta secara lahiriah, formal, materil, dan tidak sesuai denganaturan hukum tentang pembuatan akta Notaris. Asas ini tidak dapat dipergunakan untuk menilai akta batal demi hukum, karena akta batal demi hukum dianggap tidak pernah dibuat.

Dengan alasan tertentu sebagaimana tersebut di atas, maka kedudukan akta Notaris:

a) Dapat dibatalkan;

b) Batal demi hukum;

c) Mempunyai kekuatan pembuktian sebagai akta di bawah tangan; 
d) Dibatalkan oleh para pihak sendiri, dan

e) Dibatalkan oleh putusan pengadilan yang telah mempunyai kekuatan hukum tetap karena penerapan asas praduga sah.

Kelima kedudukan akta Notaris pengganti di Kota Semarang sebagaimana tersebut di atas tidak dapat dilakukan secara bersamaan, tapi hanya berlaku satu saja. Jika akta Notaris pengganti di Kota Semarang diajukan pembatalan oleh pihak yang berkepentingan kepada pengadilan umum (negeri) dan telah ada putusan pengadilan umum yang telah mempunyai kekuatanhukum tetap atau akta Notaris pengganti di Kota Semarang mempunyai kedudukan pembuktian sebagai akta di bawah tangan atau akta Notaris pengganti di Kota Semarang batal demi hukum atau akta Notaris pengganti di Kota Semarang dibatalkan oleh pihak sendiri dengan akta Notaris pengganti di Kota Semarang lagi, maka pembatalan akta Notaris pengganti di Kota Semarang yang lainnya tidak berlaku. Hal ini berlaku pula untuk asas praduga sah.

\section{Simpulan}

Kewenangan Notaris pengganti di Kota Semarang dalam pembuatan akta notaris pengganti di Kota Semarang dalam status tersangka dan perlindungan hukum para pihak. Akta yang dibuat Notaris pengganti di Kota Semarang yang statusnya sebagai tersangka tetap memiliki kekuatan pembuktian yang sempurna dengan memenuhi ketentuan Pasal 1868 KUHPerdata serta memenuhi ketentuan Pasal 16 ayat (1) huruf 1 yaitu seorang Notaris pengganti di Kota Semarang berkewajiban membacakan akta di hadapan penghadap dengan dihadiri oleh paling sedikit 2 (dua) orang sanksi dan ditandatangani pada saat itu juga oleh penghadap, saksi, dan Notaris.

Legalitas akta yang dibuat oleh notaris pengganti di Kota Semarang dalam kedudukannya sebagai tersangka. Seorang Notaris pengganti di Kota Semarang yang berstatus tersangka tetap diperbolehkan membuat akta kecuali Notaris pengganti di Kota Semarang tersebut ditahan karena seorang Notaris pengganti di Kota Semarang harus membuat akta di kantornya, jadi tidaklah dimungkinkan pembuatan akta tersebut pada saat seorang Notaris pengganti di Kota Semarang ditahan. Kepastian hukum bagi para pihak apabila notaris pengganti di Kota Semarang membuat akta dalam status tersangka. Akta yang dibuat Notaris pengganti di Kota Semarang yang statusnya sebagai tersangka tetap memiliki kekuatan pembuktian yang sempurna dengan memenuhi ketentuan Pasal 1868 KUH Perdata serta memenuhi ketentuan Pasal 16 ayat (1) hurf 1 yaitu seorang Notaris pengganti di Kota Semarang berkewajiban 
membacakan akta di hadapan penghadap dengan dihadiri oleh paling sedikit 2 (dua) orang sanksi dan ditandatangani pada saat itu juga oleh penghadap, saksi, dan Notaris.

\section{DAFTAR PUSTAKA}

Adjie, Habib. 2008. Sanksi Perdata Dan Administratif Terhadap Notaris Sebagai Pejabat Publik. Bandung: Refika Aditama.

Apeldoorn, L. J. Van. 1996. Pengantar Ilmu Hukum. Cetakan Kedua Puluh Enam. Jakarta: Pradnya Paramita.

Budiono, Herlien. 2007. Kumpulan Tulisan Hukum Perdata Di Bidang Kenotariatan. Bandung: Citra Aditya Bakti.

Chomzah, Ali Achmad. 2002. Hukum Pertanahan. Jakarta: Prestasi Putaka.

Effendi, Bactiar. 1993. Kumpulan Tulisan Tentang Hukum Tanah. Bandung: Alumni.

Hadjon, Philipus M. 1993. Pemerintah Menurut Hukum (Wet-En Rechmatig Bestuir). Cet. 1. Surabaya: Yuridika.

Kohar, A. 1983. Notaris Dalam Praktek Hukum. Bandung: Alumni.

Nico. 2003. Tanggung Jawab Notaris Selaku Pejabat Umum. Yogyakarta: Centor For Documentation And Studies Of Busines Law (Cdsbl).

Notodisoerjo, R. Soegondo. 1982. Hukum Notariat Di Indonesia (Suatu Penjelasan). Jakarta: Rajawali Press.

Salam, Moch. Faisal. 2001. Hukum Acara Pidana Dalam Teori Dan Praktek. Bandung: Mandar Maju.

Santoso, Urip. 2013. Hukum Agraria Kajian Komprehensif. Jakarta: Kencana.

Soemitro, Ronny Hanitijo. 1990. Metodologi Penelitian Hukum Dan Yurimetri. Jakarta: Ghalia Indonesia.

Tedjosaputro, Liliana. 1995. Etika Profesi Notaris Dalam Penegakan Hukum Pidana. Yogyakarta: Bigraf Publishing.

Thamrin, Husni. 2010. Pembuatan Akta Pertanahan Oleh Notaris. Yogyakarta: Laksbang Pressindo.

Tobing, G.H.S Lumban. 1999. Peraturan Jabatan Notaris. Jakarta: Erlangga.

Anand, Ghansham. 2016. "Pengawasan Terhadap Notaris Dalam Kaitannya Dengan Kepatuhan Menjalankan Jabatan.” Lambung Mangkurat Law Journal 1 (1): 44063. 
Faiz, Pan Mohamad. 2009. "Teori Keadilan John Rawls (John Rawls' Theory Of Justice)." SSRN Electronic Journal. Https://Doi.Org/10.2139/Ssrn.2847573.

Fitri, Irma Mulia. 2019. "Pengawasan Dan Pembinaan Majelis Pengawas Daerah Terhadap Notaris Yang Melakukan Pelanggaran.” Syiah Kuala Law Journal 3 (1): 53-62.

Prakoso, Wibby Yuda. 2017. “Tanggung Jawab Dan Akibat Hukum Dari Akta Notariil Yang Dibuat Oleh Notaris Pengganti Setelah Masa Jabatannya Selesai.” Jurnal Akta 04.

Rahman, Mokhamad Dafirul Fajar. 2014. "Kewenangan, Kewajiban Notaris Dan Calon Notaris Dalam Membuat Akta Autentik." Jurnal Mahasiswa Fakultas Hukum Universitas Brawijaya.

Kitab Undang-Undang Hukum Pidana.

Undang-Undang Nomor 30 Tahun 2004 Tentang Jabatan Notaris.

Peraturan Menteri Hukum Dan Hak Asasi Manusia Republik Indonesia Nomor M.02.PR.08.10 Tahun 2004.

Peraturan Menteri Hukum Dan HAM Nomor: M.03.HT.03.10 Tahun 2007 Tentang Pengambilan Minuta Akta Dan Pemanggilan Notaris Pengganti.

Nota Kesepahaman Antara Kepolisian Negara Republik Indonesia Dengan Ikatan Pejabat Pembuat Akta Tanah Nomor Pol: B/1055/V/2006 Dan Nomor: 05/PP-IPPAT/V/2006 Tanggal 9 Mei 2006 Tentang Pembinaan Dan Peningkatan Profesionalisme Di Bidang Penegakan Hukum. 